\title{
CAREER GUIDANCE OF COMPREHENSIVE SCHOOL PUPILS IN THE IMPLEMENTATION OF EDUCATIONAL REFORM IN RUSSIA
}

\author{
Ekaterina KOVALEVSKAYA \\ Department of General and Social Psychology Pskov State University \\ summereal@gmail.com
}

\begin{abstract}
This article discusses the results of research of features of career guidance of the modern Russian comprehensive school pupils in the education system reform. Author discusses about the features of professional motivation, vocational choices of pupils, the character of their preferred type of career. The study was conducted under the program of psychological support of the process of career guidance of pupils, implemented in the Pskov State University. The results confirmed the relevance of the program, and identified problems that arise in modern young people in decision-making about their future profession.
\end{abstract}

Keywords: activity, career guidance, career choices, intrinsic and extrinsic motivation, professional motivation, professional self-determination.

\section{Introduction}

At present, the main feature of the Russian education system is to carry out its reform, which affects not only the system of higher education, but also comprehensive school. Reform is in the early profiling of education, increasing the volume of workload, the implementation of the final certification as a unified state examination, etc. Carrying out these changes requires high school pupils of the earlier professional self-select the profile of training, the planned level of education, as well as a specific institution to master future profession. Therefore, it is important to study the psychology of modern pupil's career guidance in conditions of reforming the education system.

Careers are comprised of objective elements, e.g. visible activities, and subjective elements, e.g. attitudes and orientations about the career held by an individual (Gunz, 1988). Career guidance can be defined as attitudes expressed by super ordinate intentions of an individual that will influence career-related decisions (Maier et al., 1994).

The purpose of the study was to determine the characteristics of career guidance of today's young people studying in the upper grades of comprehensive schools. Based on the analysis of psychological and pedagogical literature we have identified indicators that reflect certain career guidance of pupils. These indicators include favorite types of professions (at the level I can and I want), the motives of choosing a future profession, the needs that the student intends to meet through professional activities, attitude to various types vocational education institutions, as well as the level of personal maturity. 


\section{Materials and methods}

Participants in this research were pupils of 9-10 grades of comprehensive schools in the city of Pskov, Russia. A total of 46 people participated. The age of respondents was 15-16 years. All pupils were audience pre-university training program "The course of professional self-determination", which is implemented in the Pskov State University, Department of Psychology.

This program is aimed at implementing the following tasks:

- Implementation of additional pre-university education of pupils;

- Optimization of the process of professional self- determination;

- Assistance in the professional choice;

- Increase the level of knowledge about professions and requirements for specialists.

The program is based on the use of interactive teaching methods and includes three modules:

1. Professions: classification, job duties, skill requirements (24 hours);

2. Psychology of professional choice (20 hours);

3 . The concept of professional important qualities and professional abilities (testing) (26 hours).

Research methods were tested and questionnaire method. We used the following questionnaires and tests:

- Introduction questionnaire directed at identifying characteristics of career choice of senior comprehensive school;

- Questionnaire "Orientation" (by Solomin, I. L.);

- Scale of diagnosis of personal maturity (author Kovalevskaya, E. V.);

- Questionnaire diagnosis of needs of a person to be implemented in professional activities;

- The method of semantic differential for the diagnosis of attitude to educational institutions (modification of Solomin, I. L.);

- Questionnaire "Motives career choice" (by Ovtcharova, R.V.).

The study received the following data, reflecting the characteristics of career guidance of modern senior comprehensive schools.

\section{Results}

1. Diagnostics of features of the career choice of comprehensive school pupils. The research found that only $17 \%$ of pupils have already decided on their future profession. $9 \%$ of respondents said that their parents had influence on their career choices. $5 \%$ of pupils think that their professional choices made under the influence of teachers in school, and 3\% - under the influence of friends.

Also, senior pupils of comprehensive school were asked what level of education is acceptable to them. As a result, it was found that $33 \%$ of respondents to an 
acceptable level of education are vocational education in college, for $32 \%$ Bachelor, $15 \%$ pointed to the magistracy, $3 \%$ - to postgraduate school.

Regarding the choice of educational institution $31 \%$ of pupils indicated that they wish to study in an institution of higher education in Pskov, 17\% - in the College of Pskov, 35\% - in an institution of higher education in St. Petersburg, 4\% College in St. Petersburg. Education in Moscow did not choose none of the pupils interviewed. $13 \%$ of pupils reported that have not decided to where want to learn.

In addition, $48 \%$ of pupils reported that in the future want to remain living in their region (Pskov region), 35\% - want to go live in St. Petersburg, 4\% indicated any other region, 6\% said they wanted to leave abroad (Spain, Western Europe). Living in Moscow did not choose one, $7 \%$ of pupils did not answer the question.

On the question of character their preferred schools pupils career following data were obtained: $22 \%$ of pupils choose a vertical guiding career, $17 \%$ of young people surveyed chose a horizontal career development of oneself as a professional, $61 \%$ of pupils chose a mixed career that combines both vertical and horizontal career.

2. Diagnosis of comprehensive school pupils preferred types of professions (at the level I can and I want). When analyzing the data we used two occupational classifications:

- On the subject of labor: the profession of the "human - person," the profession of the "human - technique," the profession of the "humaninformation", the profession of the "human - art" the profession of the "human - nature."

- The nature of labor: the performing and creative profession.

Diagnosis of these types of professions at the level of "I want" allowed obtaining the following results.

At a high level of preference for professions such as " human - person " was observed in $22 \%$ of pupils, at a level above the average $-17 \%$. $30 \%$ of surveyed young people do not want to choose a profession in the group.

At a high level of preference for professions such as "human - technique" is seen in $9 \%$ of pupils, at a level above the average - $13 \%$. All of the pupils did not say that absolutely refuses to choose such a profession.

High level of propensity to professions such as "human - information" was found in $4 \%$ of the pupils, the level above the average - $17 \%$. $30 \%$ of senior comprehensive schools indicated that they do not want to choose a profession in the group.

Professions such as "human - art" want to choose 17\% of pupils (high level), $9 \%$ of senior absolutely do not want to choose a profession in the group.

For professions such as "human - nature" $13 \%$ of respondents are inclined at a high level, and 13\% - higher than average. 9\% said they would not choose such a profession. 
High propensity to choose performing professions demonstrated $13 \%$ of pupils, at a level above the average - $22 \%$, lower - $17 \%$. High propensity to choose creative professions showed $17 \%$ of senior, above average - $22 \%$, lower $-17 \%$. At the level of abilities ("I can"), the following results were obtained. $13 \%$ of pupils indicated that they have a highly developed ability to professions such as "human - human." $17 \%$ believe that such p abilities are developed in them a higher than average. $17 \%$ of young people report that they can not successfully perform such profession.

High ability to professions such as "human - technique" was found in $17 \%$ of pupils above average $-13 \%$. $9 \%$ of senior comprehensive schools do not have the abilities for this group of professions.

$22 \%$ of respondents believe that they have a high level of intensity abilities to professions such as "human - information", 9\% - a level above the average. 22\% of young people surveyed said they did not have the appropriate skills.

For the successful fulfillment professions such as "human - art" have the ability to $22 \%$ of senior comprehensive school (high-level), $17 \%$ believe that these abilities they have not developed.

$13 \%$ of pupils think that at a high level have abilities required to successfully perform professions such as "human - nature", 22\% - higher than average. $9 \%$ said that they have such ability is not developed.

Tendency to the performing professions type have $22 \%$ of pupils. This propensity is not available in $26 \%$ of the respondents. $17 \%$ of pupils indicate a developed ability for creative professions. $26 \%$ of respondents believe that they have not developed skills in creative professions.

3. The level of personal maturity of the comprehensive school pupils.

Data on the level of personal maturity of senior comprehensive school, the following: $9 \%$ of pupils have a high level of personal maturity, $17 \%$ - a level above the average, $43 \%$ - average level, $22 \%$ - a level below the average, $9 \%$ - a low level. Prevailing level is the average level of personal maturity.

4. Diagnostics of needs realized in professional activities (Table 1).

An analysis of the mean values indicates that most of senior comprehensive schools want their future professional activities meet needs such as selfconfidence, good job, good earnings, communication and respect. Least of all pupils are counting on the fact that their future work will ensure the satisfaction of such needs as authority, business trip and travel, love.

5. Diagnostics of motives for choosing a profession.

This study was considered such motives career choices, such as:

1. Intrinsic motivation of choice of profession - its social and personal significance; satisfaction that brings work thanks to its creative nature, the possibility to communicate, guide other people etc. Intrinsic motivation occurs from the needs of the individual, so it is based on people working with pleasure without external pressure. 
2. Extrinsic motivation - its earnings, the desire for prestige, fear of condemnation, failures, etc. External motivation can be divided into positive and negative. The positive motives are: material incentives, opportunities for promotion, the approval of the team, prestige, incentives for which a person considers it necessary to make an effort. The negative effects are based on the person by the pressure of punishment, criticism, condemnation and other sanctions of a negative character.

Table 1

\section{Needs of the pupils they want to implement in future careers}

\begin{tabular}{|l|l|c|}
\hline No & \multicolumn{1}{|c|}{ The need } & Mean \\
\hline 1 & material well-being & 7,8 \\
\hline 2 & safety & 7 \\
\hline 3 & communication & 8,1 \\
\hline 4 & freedom & 7,7 \\
\hline 5 & success & 7,9 \\
\hline 6 & creation & 7,1 \\
\hline 7 & good job & 8,4 \\
\hline 8 & respect & 8,1 \\
\hline 9 & good earnings & 8,3 \\
\hline 10 & business trip and travel & 4,7 \\
\hline 11 & stability in life & 7 \\
\hline 12 & love & 5,9 \\
\hline 13 & fulfillment of duty & 6,9 \\
\hline 14 & career & 7,2 \\
\hline 15 & authority & 4,2 \\
\hline 16 & personal independence & 6,8 \\
\hline 17 & trust & 7,2 \\
\hline 18 & new knowledge & 7,8 \\
\hline 19 & responsibility & 7,1 \\
\hline 20 & self-confidence & 8,8 \\
\hline
\end{tabular}

Pupils demonstrate the following character of such motives:

$1.35 \%$ of respondents indicate a high level of internal representation of individually significant motives in structure of professional motivation. In $52 \%$ of the pupils such motives are observed on average. 13\% of young people have a low level according to motives.

2. $22 \%$ of young people believe that they have a high level of intrinsic motivation of choice of profession, which has social implications. 77\% believe that the motivation to have in their average level. $13 \%$ of respondents indicated a low level of the motivation.

3. $17 \%$ of pupils have a high level of external positive motivation, $66 \%$ - the average level of $17 \%$ - a low level.

4. $9 \%$ of senior comprehensive schools have a high level of external negative motivation, $74 \%$ - average level of $17 \%$ - a low level. 
Prevailing level is average for all kinds of motives for choosing a profession. Intrinsic professional motivation, which has individual significance, dominated a large part of the respondents.

\section{Conclusions}

The study revealed a character of career guidance of modern senior comprehensive school in Russia:

1. Only $17 \%$ of pupils say with confidence that self-made career choices. Other respondents have made this choice under the influence of any external factors. Only $15 \%$ of pupils prefer to get a master's degree. Most of the pupils will be satisfied with less and low levels of education. Only $48 \%$ of pupils want to live in the future in the region. The rest of the respondents prefer to go to a big city or even abroad. Most of the pupils (61\%) wish in the future to combine vertical and horizontal career, that is, want to develop as a professional and as a leader.

2. Most of the pupils of comprehensive schools at the level of "I want" chosen profession "human - human." At the level of "I can" most of the pupils choose a profession "human - information." The level of personal maturity as a condition for a responsible and independent professional student selection is average for the majority of respondents.

3. Possible to allocate following needs that senior comprehensive school would like to satisfy in the future professional activity: self-confidence, good job, good earnings, communication and respect. In this case, the majority of pupils appear the intrinsic motivation of choice of profession, which has individual significance. They are focused on ensuring that future profession could create the conditions for self-development, creativity and communication.

\section{References}

1. Gerber, M., Wittekind, A., Grote, G., Staffelbach, B. (2009). Exploring types of career guidance: A latent class analysis approach. Journal of Vocational Behavior, doi:10.1016/j.jvb.2009.04.003.

2. Gunz, H. (1988). Organizational logistics of managerial careers. Organization Studies, 94, 529-554.

3. Maier, G. W., Rappensperger, G., Rosenstiel, L. V., \& Zwarg, I. (1994). Berufliche Ziele und Werthaltung des Führungsnachwuchses in den alten und neuen Bundesländern (Professional aims and values of future leaders in the old and new federal states).

Zeitschrift für Arbeits-und Organisations psychologie, 38, 4-12.

4. Ковалевская, Е. В. (2013). Курс профессионального самоопределения. Программа профориентационного развивающего тренинга / учебно-методическое пособие для психологов и педагогов. СПб, «АЙСИНГ».

5. Соломин, И. Л. (2008). Экспресс-диагностика персонала. СПб, Речь. 